Published on Reviews in History (https://reviews.history.ac.uk)

\title{
Tears of Rangi: Experiments Across Worlds
}

Review Number: 2281

Publish date: Thursday, 13 September, 2018

Author: Anne Salmond

ISBN: 9781869408657

Date of Publication: 2017

Price: $£ 62.50$

Pages: 512pp.

Publisher: University of Auckland Press

Publisher url: http://www.press.auckland.ac.nz/en/browse-books/all-books/books-2017/tears-of-rangi.html Place of Publication: Auckland

Reviewer: Michael Belgrave

Dame Anne Salmond is one of New Zealand's most respected public anthropologists and historians. No one has so effectively and lucidly crossed over between the two disciplines in New Zealand scholarship. Her interpretation of New Zealand's past has had a wide and receptive audience and her now extensive body of work has been immensely important role in helping to normalise being M?ori in a non-M?ori world. Beginning as an anthropologist with a passing interest in history, she has produced a series of groundbreaking books explaining this world to non-M?ori and M?ori audiences. Her study of hui (ritualised forms of M?ori meeting and discussion) extended from her doctoral thesis and built on her relationship with a remarkable couple, Amiria and Eruera Stirling.[1] She then facilitated autobiographies of both Amiria and Eruera.[2] Through the 1980s most of her focus was on M?ori epistemologies. Then a dramatic change in direction. In 1991 she produced Two Worlds: First Meetings Between M?ori and Europeans, 1642-1772, where she largely followed J.C. Beaglehole on his journey following James Cook on his three voyages to New Zealand, with Dutch and the French thrown in. Unlike Beaglehole her gaze was on the cultural exchange between Europeans and Polynesian peoples, turning M?ori from subjects of European vision to animated and equal participants in fascinating encounters between peoples of different worlds; in Salmond's view equal worlds. A series of books followed on New Zealand and the Pacific in the early contact period extending both her theme and her method. [3]

Tears for Rangi revisits old voyages and explores new ground. The book is part history, part anthropology and comparative philosophy, part public policy and part autobiography. It starts with the beginning of her intellectual journey, with the Stirlings, revisits her large books on Cook, and moves into relationships between the Anglican missionaries and M?ori through to the 1830s, spending a good deal of time with Henry Williams and James Busby running up to He Whakap?tanga (The Declaration of Independence, 1835) and Te Tiriti o Waitangi (1840), on which the current New Zealand Constitution's claims of legitimacy rest. Then follows a series of chapters which are present- focused dealing with rivers, land, the sea and people, largely through a series of questions being considered in a variety of different inquiries by the Waitangi Tribunal.

Tears of Rangi provides an opportunity to review not only a single work, but Salmond's own approach to history, developed over half a century, and culminating in her latest book. Her first books provide the key to 
understanding Salmond's perspectives. In Hui she demonstrated the complexity and varied world of M?ori relationships and ritual, revealing the resilience of these in the face of colonisation, but also showing how varied these practices were tribe by tribe, location by location. Produced in the 1970s, when the forces of assimilation seemed all but insurmountable, she was far from confident that these cultural forms would survive, particularly given the impact of urbanisation on the young. She feared that the new generations of M?ori in cities and towns, away from their cultural hearths, would become isolated from their roots and lose contact with these cultural practices and the ways of thinking that defined them as M?ori. Half a century on, Tears of Rangi is a testament to continuing M?ori resilience, not so much because of the persistence of cultural practices, but because of the intellectual and cultural heft behind them.

Her books are long, highly detailed and her arguments complex and far from free of academic jargon. Nonetheless, she is an exceptional storyteller. Tears of Rangi is no exception. For European readers, Salmond demonstrates the vitality and resilience of the M?ori world. For M?ori readers she reinforces an increasing sense of pride in M?ori-centred perspectives and even in M?ori science. Compared with some of the histories being published today, she does not expect non-M?ori readers to feel personally responsible for the colonial past, does not populate her books with European villains and tries to understand rather than blame. She almost invariably treats her historical figures sympathetically and with dignity. While she is highly critical of European claims to intellectual and cultural superiority, she places these in cultural rather than personal contexts.

Her generosity of spirit sits alongside an unshakeable confidence in her own ideas and arguments from her own extensive reading of primary sources. Her history stands outside historiography. She rarely if ever refers to the arguments of other historians and there are notable omissions from her bibliography, including for instance, Richard White's highly influential Middle Ground, whose terminology she shares, and Andrew Sharp's monumental biography of Samuel Marsden (although Sharp's book may well have arrived too late to be included).[4] It would not have mattered as Salmond the historian, rather than Salmond the anthropologist, makes but passing use of the literature on the topics she covers, despite the 1820s to the 1840s and British intervention in New Zealand being the most well-travelled of New Zealand's histories. In her detailed coverage of the errant missionary, Thomas Kendall, she dedicates her chapters in her references to Judith Binney's landmark Legacy of Guilt, but makes no other mention of this work, from which she draws extensively. Her chapter on He Whakap?tanga me te Tiriti refers to some historians, but not the detail of vast historical debate taking place before the tribunal in that claim, which took over 600 pages for the tribunal to summarise. Despite being seen very much as a historian, and with good reason, her disciplinary home is still anthropology and rooted in her early experience as a student in the discipline. At times this creates problems, for her command of narrative makes her accounts of events and also their interpretation appear objective truths, rather than extending from careful and transparent debate with a sophisticated literature. There are hints that she treats this literature as too rooted in Enlightenment methodologies to be taken seriously as being 'shaped by reliance on documents written in English and underpinned by modernist habits of mind', certainly for any history written without immersion in te ao M?ori.[5]

Her own immersion in te ao m?ori began very early and has its roots in her own family history and through the mentoring of the Stirlings. In a discussion which concludes the autobiography of Eruera Stirling, she produced a manifesto on the future of anthropology in New Zealand as she saw it.

I take anthropology to be not a science, but a humanity in the true sense of the word. Its proper task, I think, is to seek to understand and communicate cultural differences, and in its finest moments to bridge them. At this level anthropology is rooted both in our common humanity and our construction of different worlds of meaning, and wherever people find themselves living side-by-side (as M?ori and pakeha do in New Zealand) and yet cultural worlds apart, some such attempted talking out our differences seems to me inevitable.[6]

She went on to say that she dreamt 'of an anthropology for New Zealand that celebrates both our common humanity and our cultural differences, drawing strength from one without detracting from the other'. [7] She has been true to these long stated objectives throughout her career. Tears of Rangi is concerned with the 
'construction of different worlds of meaning', and in this book she extends and develops this idea well beyond what has gone before.

While she covers some of the same explorations and encounters of her earlier books, beginning with Two Worlds, this time her messages is more distilled, focused on ontologies, the ways societies consider the nature of being. Salmond's approach in Two Worlds drew on methods of anthropology for its intellectual framework and history for its primary source informed narratives. It was based on her understanding of the M?ori world she had obtained through the Stirlings and her ongoing relationship with M?ori. She animated the indigenous lives sketched in the European journals of 17th- and 18th-century explorers using methods and perspectives ignored or unavailable to the earlier historians. The results were lively and human narratives. She did over-generalise the European world, from a limited range of secondary sources, and was criticised in a bruising but partisan attack from Peter Munz for her use of anthropological and historical theory.[8] But these aspects of Two Worlds were peripheral to her primary objectives of bicultural storytelling and this she did extraordinarily well in recognising the vitality and viability of the M?ori world.

Although she covers the same ground in Tears of Rangi, her purpose is far grander. What were once largely human encounters, from people with different cultural backgrounds and experiences, are now examples of much larger ontological clashes, where two ways of interpreting reality, two understandings of time, relationships, power and authority, meet head-on. The book begins with reference to the claims of Viveiros de Castro, that all the world's peoples have a right to 'ontological self-determination'.[9] Her objective is as political as it is intellectual. Her two worlds are two intellectual and cultural spaces, where reality is defined and performed and each is very different from the other. Exploration and contact through the expansion of Europe placed these worlds in collision and colonisation gave one ascendancy over the other in defining reality.

Nonetheless, Salmond argues that these ontological engagements are positive. They shakeup things, allow for new ways of communicating whether between Hongi Hika and Thomas Kendall or in the negotiations over settlement of the Whanganui River claim, and the development of the idea of a legal personality of the river itself. The M?ori world is based on 'the rhizomatic, ramifying networks of whakapapa, powered by exchange and ideas of mana and tapu' $\underline{[10]}$ Her te ao M?ori is an integrated universe, where time is nonlinear, where all things are integrated by whakapapa, across time and space, all animated by the hau, the vital breath. Inter-relationships and reciprocity govern all things. None of this is static, and the pae, the place were debate and encounters take place, allows new things to emerge. However, with a lifetime experience of the M?ori world, Salmond does more than articulate M?ori cosmology and the principles on which it rests in ways that are creative and convincing. Her skilled rhetoric and her intellectual and anthropological fluency poses a risk of providing a defining statement of te ao M?ori, and in so doing becoming a substitute for the thing it describes. Her use of anthropological terms and concepts normalise te ao M?ori for anthropology, but it also normalises anthropology (and its terminology) within te ao M?ori.

In contrast, the European world is divided by a Cartesian dualism. Mind is separated from matter, civilised from savage and barbarous peoples and humankind from nature. Time is linear, tracing the history of civilisation from hunters and gatherers to modernity. Salmond makes much of the Enlightenment's stadial idea of economic and cultural progress where indigenous societies are located on a path towards modernity, depending on how much they reflected idealised periods in the European past. She notes the tendency of European commentators to liken early 19th-century M?ori society with British society at the time of the Roman invasion. But she also links these 18th-century interpretations to the much older notion of the Great Chain of Being, which provides a much less flexible (and a very non-Cartesian) cosmology of relationships, linking all things in a hierarchy from God and his angels to rocks at the very bottom. Salmond admits the complexity of Enlightenment thought, and even locates some of these debates on Cook's Endeavour itself, but in the end both the M?ori and the European ontologies are idealised and universalised and very distinct. They govern perceptions of self and of others and they create between them an almost unsurmountable gulf. In her earlier books, the two worlds were social and economic and well as intellectual spaces, but in Tear of Rangi they are almost entirely intellectual. Economics and society do not exist alongside ideas; they flow 
from them.

There are many aspects of European thinking that are ignored, which could have suggested greater common ground, particularly the way that European history is also genealogical and relationships familial and that Romanticism had much more of an organic view of the universe than did Adam Smith (although the 18thcentury Adam Smith also had a much more organic and theistic view of the universe than did the reincarnated Adam Smith of the two centuries since). Nor does she consider common ground between mana and status significant, although she does demonstrate their interaction on many occasions. While Evangelical Christianity was influenced by the Enlightenment, there were significant differences between the two which undermine the cohesion of her modernist ontology, and the Catholic ideas supporting the French Marist mission were barely touched by the Enlightenment. The Samuel Marsden of Andrew Sharp's biography has ambivalent views on M?ori cannibalism, sees M?ori behaviour, when not engaged in warfare as superior to that of most Europeans and, far from fixing M?ori in some inferior place on a Great Chain of Being, has them capable of levels of civilisation beyond that of the European world. True, all of this required the Grace of God, but that is pretty much all. Marsden's divine order is not split by Cartesian dualism. Marsden's assessment of M?ori civilisation was also not drawn from the economic measures of the Scottish Enlightenment, but from what he saw as their responsiveness to God's message, declaring them at one time, 'far more likely to embrace the Gospel than any other nation of civilised heathens'.

Salmond sees the engagement between her two worlds as creative, but in Tears of Rangi, there is little evidence of synthesis over the centuries of contact: the worlds are separate in the 18th century and they remain separate today, this despite her evidence of some M?ori use of the language of modernity. Yet she ends confident that a global future may be more defined by a resurgent te ao M?ori than by Enlightenment economics and science. On issues such as land and water, fish and forests, the Waitangi Tribunal today is the pae, where these two worlds now face each other, just as the beach (or even Cook's cabin) had been for Cook and Tupaia two and a half centuries before. M?ori continue to insist, as they have always done, on kaitiakitanga as a foundation with relationships with taonga such as rivers, while on the European side, it is about the ability to control natural resources and profit from them.

If the M?ori world is ontologically stable, despite its ability to absorb change, then how do we make sense of debates between M?ori about engagement with the European world, about whether to adopt institutions unthinkable before the coming of Europeans, such te ture (the law), K?ngitanga or M?ori parliaments? Above all, how do we explain M?ori engagement with Christianity? In Tears of Rangi, Salmond deals with missionary Henry Williams in some depth, but ignores the consequences of conversion to Christianity and the impact of the ideas and values on which this rests. If as she acknowledges, M?ori were giving up such time honoured practices as polygamy, kai tangata (cannibalism) and releasing slaves, this must have had an impact on M?ori ontology. If it did not, then she needs to explain why. Because she does not deal except in passing with the M?ori world between 1840 and the late 20th century, she may not have to explain how her arguments about two separate ontologies play out in the ideas of Wiremu Tamihana Tarapipipi, Rua Kenana, Te Whiti o Rongomai and Tohu Kakahi and Wiremu Tahupotiki Ratana.[11] But she is certainly aware of these movements and even of the highly respected literature behind them. Hirini Kaa's informative and highly nuanced discussion of M?ori Anglicanism, which shows iwi like Ng?ti Porou adopting and adapting Anglicanism for M?ori purposes is nowhere here.[12]

She gives Tareha of $\mathrm{Ng}$ ?puhi the last word on this question, perhaps revealing her position. Tareha rejected Christianity, and she records him listening to a sermon by Williams on equality of all men before God. He, 'roaring like a bull', dismissed the whole idea with the emphatic 'such beliefs might do for Slaves and Europeans but not for a free and noble people like Ngapuhi'.[13] But such ideas certainly did do for slaves, who would, once released, become the evangelists of the new religion, taking these new ideas to their own iwi well in advance of European missionaries, as Salmond records. But she has also misread the entry in Williams's journal with significant consequences for her argument. Tareha did not attend Williams's service in Paihia and his anger was not directed at the CMS missionary. He challenged the Christian and $\mathrm{Ng}$ ?puhi Rawiri Taiwhanga at Kororareka on doctrine written in M?ori in the Anglican Catechism. [14] Even as early 
as 1833, ontological engagement had gone beyond M?ori on one side and European on the other, it had already become independently enmeshed within the M?ori world and in the new media of writing and printing.

Only when it comes to the chapter on people does Salmond have the M?ori world swayed by the influence of European law and culture and here she does blame Christianity. A world where once women and children were treated honourably and without violence has at least to some extent been replaced by something that resembles at its worst Jake Heke of Once Were Warriors. Again, Salmond uses a limited range of sources to idealise the relationships between men and women and the treatment of children (while admitting that the treatment of slaves could be very different), juxtaposing an equally idealised but violence and exploitative view of the European world. Salmond argues that European views, as mediated through missionary and Christian teaching, and through the marginalisation of women in the law, were effective in allowing for the subjugation even in kawa (cultural practices on the marae) and t?kanga (law) of at least some M?ori women. Not surprisingly, she also shows how many M?ori women including Eruera Stirling's mother, the formidable Mihi Kotukotuku, were able to at least in part to resist this relegation to inferior status. While some women did sign the treaty, she blames the European negotiators for preventing many more. Here I think Salmond has a problem. Her overarching argument is that M?ori ontological views in the present reflect those of the past, accommodating change, but far from being overwhelmed by it. And yet on the issue of the treatment of women and children, European ideas were able to undermine fundamental principles of M?ori relationships and do so at a time when M?ori were still dominant. She cannot have it both ways.

Her chapter on He Whakapf?tanga me Te Tiriri provides an example of both the strengths and the weaknesses of Salmond's approach. It does not quite start as she intended. She entitles the chapter 'Our Words Will Sink like a Stone', from a submission made by Dr Patu Hohepa, who quoted Mohi Tawhai's well known warning to the future.

Our sayings will sink to the bottom like a stone, but your sayings will float light, like wood of the whau tree, and always remains seen. Am I lying?[15]

Salmond knows the quotation well and has used it many times, including as the opening lines of Two Worlds , but here she has wrongly attributed it to another rangatira of another iwi, Panakareao from Muriwhenua (whom she also know well).[16] Hohepa's submission, with its anger at the 'lies of Hobson and others', demonstrates the highly charged, highly polarised and even theatrical nature of the tribunal inquiry in Northland. The claimants were determined to use the hearings to demonstrate that they had not ceded their sovereignty to Hobson, when they put their names to the Treaty of Waitangi. The Crown and its witnesses were clearly the enemy, held symbolically responsible for insisting that $\mathrm{Ng}$ ?puhi submit to the English laws of 19th-century governors and, eventually, to those of the European-dominated New Zealand Parliament. The Waitangi Tribunal had in the past hovered close to the point of denying that M?ori had ceded sovereignty in the treaty, while at other times seeming to accept it. The claimants went into this enquiry, with its focus on the two constitutional events resting on the mana of the $\mathrm{Ng}$ ?puhi, determined that once and for all they would demonstrate that they had not willingly given up their mana and their tino rangatiratanga to the Crown.

Salmond works this polarisation into her argument. She contrasts M?ori ability to reconstruct from M?ori knowledge the principles and world views which governed M?ori actions before 1840, and certainly at the Treaty of Waitangi, with the stadial document driven texts of European scholars. The pae of the tribunal she sees as the expression of her ontological divide.

In front of the Waitangi Tribunal 170 years later, however, witnesses with little knowledge of the M?ori language, ancestral practices or habits of mind often spoke confidently about life in the Bay of Islands and M?ori negotiations over the Treaty in 1840, without realising how far their understandings were shaped by reliance on documents written in English and underpinned by modernist habits of mind. [17] 
The divide was real enough, but Salmond's forcing these divisions into different methodological approaches and understandings of knowledge is misleading. Her own approach to her chapter in Tears of Rangi and her participation in the inquiry is evidence enough. As a piece of narrative, the chapter superbly summarises the events leading up to and including the Treaty of Waitangi and its signing in Northland. She had the benefit of the tribunal's almost exhaustive report on which to draw, but nonetheless, this concise account is as good as any of the many that have gone before. But it is also, to use Salmond's term, modernist. In structure and use of evidence it, differed only in some points of interpretation with the vast bulk of the evidence presented by the Crown's and Tribunal's historical witnesses. Her chapter is purged of the oral history narratives that claimants presented to the tribunal, because in key points the detail of this evidence (rather than its overall message which Salmond does capture) were not credible, and the tribunal also avoided them. Unlike Hopeha, she does not blame Hobson.

Salmond's own position, understandably shared by many of the claimant witnesses, rejected any suggestion that M?ori evidence before the tribunal had in any way been influenced by ideas and explanations coming from outside, not only from outside the M?ori world, but from outside the perspectives of the individual iwi involved. The content and focus of the evidence suggested otherwise. M?ori evidence was dominated by the notion that there were two treaties, an English text to be rejected, and the M?ori text to be embraced. The problem, and it was repeatedly expressed in this way, is that the Crown had imposed a fake text, by relying on the English draft of the treaty, which transferred complete sovereignty while the M?ori text simply confirmed and promised to protect M?ori in their sovereign rights. Here, Salmond's inability or unwillingness to engage with historiography lets her down. She argues that it is now 'almost universally agreed' that the two treaties 'express very different understandings of future relations between M?ori and Europeans'. [18] This is just not case. More recent interpretations, including my own, stress a much greater degree of harmony between the two texts, without arguing that M?ori consigned all rights of sovereignty to the Crown. More importantly, the whole emphasis on the two texts can be criticised and Anne Salmond's material provides good support for this argument. The texts themselves play a minor role in giving meaning to the events around the signing of the treaty. It is only the capture of the Treaty of Waitangi by legal forums, such the courts and the Waitangi Tribunal, that has allowed the text of the Treaty of Waitangi to overwhelm the context, including the M?ori context of the Treaty.

Until relatively recently M?ori used both versions of the Treaty of Waitangi as it suited them and the English version, explicitly identifying forests and fisheries, was more useful in some litigation. M?ori grievances against the Crown leading to the Northern War of 1845 can all be justified as breaches of even a narrow reading of the English text. Restriction on felling of kauri was clearly in violation of article two's promise in English to protect 'exclusive and undisturbed' possession of forests and taking as Crown land, land not awarded to settlers, but not sold to the Crown by M?ori was also a clear breach of the article two text in English. No right to impose excise duties was negotiated in any form at Waitangi. Until the 1980s it did not matter much which text of the Treaty of Waitangi was appealed to, the courts considered both beyond their jurisdiction. Either one could be a symbol of promises broken. Historically, M?ori appeals to the treaty combined protest over resources lost and rights to constitutional autonomy: they often challenged the authority of the New Zealand Parliament to make law over M?ori. However, they very rarely questioned the sovereignty of the monarch and often appealed to the monarch to protect M?ori from the powers of the New Zealand Parliament. The idea that there were two very different treaties on 5 February 1840 is, in recent decades, largely due to the influence of Ruth Ross's 1972 article in the New Zealand Journal of History, which has played a dominant role in interpreting the treaty negotiations ever since.[19] Academics and lawyers latched onto Ross's view that the M?ori text of the treaty did not adequately transfer sovereignty. This provided academic support to tribal histories that denied the Crown's assertions that ancestors had given the Crown powers to impose laws on M?ori without their explicit consent. Ross's conclusions clearly influenced Ranginui Walker in his highly influential 1991 M?ori history Ka Whawhai Tonu Matou: Struggle without End and Walker sat on the Northland Waitangi Tribunal.[20]

To explain how these two very different treaties emerged, Ross blamed Henry Williams's duplicity in his 
drafting the Treaty of Waitangi and presenting it to rangatira in a way that would limit M?ori understandings of the transfer of sovereignty. He used kawanatanga, when he should have used mana to describe what was being given up to Queen Victoria. This is a view that Salmond also owns, and one of the few positions where she was in conflict with many of the other historian witnesses. In my view, whereas Henry Williams could and did use the term mana in the Declaration of Independence, as something that M?ori possessed, he could not use it for sovereignty in the Treaty of Waitangi, because sovereignty in that context had to be transferable, and mana was not. Without this level of deliberate deception, two treaties that are so different in intent and meaning could not have emerged. Ross is right about that, but she saw no problem in blaming Henry Williams as she thought little of missionaries. Salmond on the other hand recognises Henry Williams as an honest and forthright individual, whatever other faults he may have had, but still implicitly accuses him of deception in his work as the Treaty's translator. A recent legal history of the English treaty by Ned Fletcher, which Salmond cites, argues that 'British sovereignty was not seen as inconsistent with plurality in government and law.' [21] Salmond largely dismisses this because it does not explain 'why Williams used such different terms to translate this key concept in M?ori in He Whakaputanga and Te Tiriti'. On the contrary, it provides a very clear explanation of why in the Treaty of Waitangi he tried to balance the powers being given the governor and those retained by rangatira. In short, the idea that sovereignty would be shared is consistent with both the English and M?ori texts of the treaty, when understood in the specific context of 1840 .

Exploring the context of the Treaty of Waitangi provides in many ways a better platform for appreciating M?ori understandings of the Treaty than endless speculation on the meaning of the texts. First, there is almost no discussion at all in the 20 years after the signings of the specific articles of the Treaty, undermining the argument that the wording of the texts was fundamentally important in M?ori understanding of the event. There was also no appreciation that the Treaty of Waitangi extinguished M?ori rights for rangatira to continue to control the affairs of iwi. Far from seeing the treaty as only respecting M?ori self-government at a tribal level, a significant number of M?ori would argue that the treaty gave them the right to be part of the new constitutional structures created by the governor. Above all, rangatira argued that the Queen Victoria had promised to protect M?ori from the greed of settlers. Modernist scholarship, the tainted and partial lens Salmond used to condemn some of the history presented in the hearing, provided a very substantial part of the argument in support of long-held and strongly believed understandings that M?ori rightfully retained and should continue to retain lawful authority over all things M?ori. M?ori ability to borrow without compromise or at least knowingly aware of the consequences of such compromises should be more celebrated.

Salmond ends in arguing that M?ori pathways provide alternatives to contemporary capitalist modes of production and relationships based on Cartesian dualism. Networks, the underlying feature of whakapapa, provide more sustainable and appropriate ways of managing communities. I am not so confident that capitalism can be explained as the embodiment of Christian and Enlightenment ideas. To make her argument fit, she down plays or ignores some difficult issues. In her section on the sea, she champions M?ori antiglobalisation and anti-capitalism protests of the last decade, critically dismissing in little more than a page the Sealord settlement of 1992 which made M?ori major players in New Zealand's commercial fisheries. Yet this capitalist solution of M?ori grievances over fisheries was also the result of the pae, created before the tribunal and in the treaty settlement negotiations. The tribunal heard fisheries claims over resource loss and economic marginalisation and the settlement turned them into fishing quota and shares.

M?ori corporations do attempt to maintain the principles of te ao M?ori in their business practices, but M?ori fishing is still a business, has to exist in an international capitalist market, and has to provide profits for its beneficiaries. Moreover, tribal charitable trusts and corporations, which are also modernist or capitalist vehicles, attempt to balance corporate goals with grass-roots relevance to their marae and widely spread tribal populations. A thriving M?ori fishing industry in a capitalist world is as much a product of the Treaty of Waitangi today as is giving a legal identity to the Whanganui River. Salmond has confidence in the Waitangi Tribunal to be a place where these two ontological worlds can productively engage with each other. But it might be just as easily to conclude that the Treaty settlement process has incorporated M?ori 
much more effectively into modernity and capitalism, than that achieved by the Native Land Court in the 19th century. Recognising kaitiakitanga in the Whanganui River is an example on one aspect of Treaty settlements, creating corporate tribal enterprises is the more common experience of iwi settling with the Crown. Some have done well, other with less capital to begin with have been far less successful.

Salmond is hopefully right, te ao M?ori will survive: it has survived bigger challenges in the past. However, M?ori resilience can be seen as built on far more engagement and incorporation of modernity than Salmond appears prepared to admit. Tupaia used European tools to create Polynesian arts, Hongi adopted European weapons to pursue traditional competitive claims against neighbours and kin. But eventually, surprisingly quickly even, M?ori would not be in one world using the tools of another. They were living in both worlds simultaneously. I am drawn back to the image of Amiria Stirling as a young girl over a century ago, living in Wellington going out with a P?keh? boyfriend, believing in romantic love and that young women should make their own choices about whom they marry. Her values and aspirations were quintessentially modern. The M?ori world had different views of her future and arranged her highly successful taumau (arranged marriage) with Eruera Stirling, very much against her wishes and a union that at the time she strongly resisted.

For a historian with no claims to be an anthropologist, working in the world from the middle of the 1830 s to the late 20th century, a time period Salmond explores barely at all, what has been notable has been M?ori engagement with modernity, mobilising its ideas and resources while retaining something fundamentally M?ori along the way. Modernity is yet another tool of resistance. As an anthropologist, Salmond sees M?ori resilience as cosmological and epistemological. I see this resilience in the persistence of institutions such as hui, which Salmond explored over four decades ago. But as a historian, I see M?ori resilience as also tied to a myriad of highly contested and very specific histories of mana. These are malleable and creative enough to absorb new ideas and reinvent the past as all living societies do. In the end, these histories still link living people to rivers, to the land and the sea and to each other and the past to the present. Salmond's idealised worlds appear to me too hard edged, too impermeable and too non-transferable. They do not allow enough space for the huge degree of intellectual and cultural engagement which has taken place within the M?ori world through its renewed contact with the world beyond Aotearoa after 1830, despite her hope that te ao M?ori may show the way in reforming a damaged globe. They also ignore the economics and demography of colonisation, but that is another story. Tears of Rangi is a magnificent enterprise: but its strengths should not crowd out other possibilities.

[1] Anne Salmond, Hui: A Study of Maori Ceremonial Gatherings (Wellington: Reed, 1975).

[2] Amiria Manutahi Stirling and Anne Salmond, Amiria: The Life Story of a Maori Woman (Wellington: A. H. \& A. W. Reed, 1976); Eruera Stirling and Anne Salmond, Eruera, the Teachings of a Maori Elder (Wellington: Oxford University Press, 1980). 
(Auckland: Viking, 1997); The Trial of the Cannibal Dog: Captain Cook in the South Seas (London: Allen Lane, 2003); Aphrodite's Island: The European Discovery of Tahiti (Auckland: Viking, 2009); Bligh: William Bligh in the South Seas (Auckland: Viking, 2011).

[4] Richard White, The Middle Ground: Indians, Empires, and Republics in the Great Lakes Region, 16501815, Cambridge Studies in North American Indian History. (Cambridge New York: Cambridge University Press, 1991); Andrew Sharp, The World, the Flesh \& the Devil : The Life and Opinions of Samuel Marsden in England and the Antipodes, 1765-1838 (Auckland: Auckland University Press, 2016).

[5] Anne Salmond, Tears of Rangi: Experiments across Worlds (Auckland: Auckland University Press, 2017), p. 247.

[6] Stirling and Salmond; ibid, p. 253.

[7] Ibid, p. 254

[8] Peter Munz, 'The Two Worlds of Anne Salmond in Postmodern Fancy-Dress', New Zealand Journal of History, 28, 1 (1994). See also, Salmond's reply to Munz, 'Antipodean Crab Antics', New Zealand Journal of History 28, 1 (1994), 76-9.

[9] Salmond, Tears of Rangi: Experiments across Worlds, p. 1.

[10] Ibid.

[11] Judith Binney, The Legacy of Guilt; a Life of Thomas Kendall (Auckland: Published for the University of Auckland by the Oxford U.P, 1968); Judith Binney, Gillian Chaplin, and Craig Wallace, Mihaia: The Prophet Rua Kenana and His Community at Maungapohatu (Auckland: Auckland University Press/Oxford University Press, 1979); Judith Binney and Gillian Chaplin, Ng? Morehu. The Survivors (Auckland: Auckland University Press, 1986); Judith Binney, Redemption Songs. A Life of Te Kooti Arikirangi Te Turuki (Wellington: Auckland University Press/Bridget Williams Books, 1995); "Christianity and the Maoris to 1840: A Comment," New Zealand Journal of History 3, no. 2 (1969).

[12] Hirini Kaa, "He Ng?kau Hou: Te H?hi Mihinare and the Renegotiation of M?tauranga, C.1800-1992" (University of Auckland, 2014).

[13] Salmond, Tears of Rangi: Experiments across Worlds, p. 258.

[14] The actual quotations were 'roaring like an infuriated bull' and 'This doctrine as observed may do for Slaves and Europeans but not for a free and noble people like the Ngapuhi, therefore they will not receive it'. Henry Williams, The Early Journals of Henry Williams, Senior Missionary in New Zealand of the Church Missionary Society; 1826-40, ed. Lawrence M. Rogers (Christchurch: Pegasus Press, 1961), p. 278.

[15] Salmond, Tears of Rangi: Experiments across Worlds, p. 247.

[16] Two Worlds: First Meetings between Maori and Europeans, 1642-1772 (Auckland: Viking, 1991), p. iii;

[17] Tears of Rangi: Experiments across Worlds, p. 247.

[18] Ibid, p. 263.

[19] R. M. Ross, "Te Tiriti O Waitangi: Texts and Translations," New Zealand Journal of History 6, no. 2 (1972).

[20] Ranginui Walker, Ka Whawhai Tonu Matou: Struggle without End (Auckland: Penguin, 1990). 
[21] Ned Fletcher, "A Praiseworth Device for Amusing an Pacifying Savages? What the Framers Meant by the English Text of the Treaty of Waitangi" (University of Auckland, 2014), cited Salmond, Tears of Rangi: Experiments across Worlds, p. 285.

\section{Other reviews:}

Story Mint

https://www.thestorymint.com/content/tears-rangi-book-review [2]

Spinoff

https://thespinoff.co.nz/books/25-11-2017/historian-anne-salmond-how-a-spinoff-reviewer-got-it-wrongabout-my-new-book/ [3]

Source URL:https://reviews.history.ac.uk/review/2281

\section{Links}

[1] https://reviews.history.ac.uk/item/293497 [2] https://www.thestorymint.com/content/tears-rangi-bookreview [3] https://thespinoff.co.nz/books/25-11-2017/historian-anne-salmond-how-a-spinoff-reviewer-got-itwrong-about-my-new-book/ 